\title{
Determining the Chemical Compositions of Garlic Plant and its Existing Active Element
}

\author{
Reyhaneh Mardomi \\ ${ }^{I}$ (Department of Chemistry, Islamic Azad University Central Tehran Branch, Iran)
}

\begin{abstract}
In this research, we investigate the process of producing allicin in garlic. With regard to the chemical compositions of garlic (Allium Sativum L.), allicin is among the active sulfuric materials in garlic that has a lot of benefits such as anti-bacterial, anti-oxidant and deradicalizing properties.

Keywords: the chemical compositions, Garlic, Allicin
\end{abstract}

\section{Introduction}

Allicin was first reported in 1944 by Cavallito and Bailey, who described it as a colorless oil with low solubility in water that was relatively unstable. Allicin derives from the precursor alliin through the enzymatic activity of alliinase. According to Murray.Garlic is one of the most widely used medicinal plants since ancient times. It was used by the Egyptians, Greeks and Romans.

The researches performed on garlic plant represent that the key element and composition of garlic is constituted of alliin element. Name of garlic is most probably extracted from celtic i.e. harsh.

Amino acid alliin is an alkyl amino extracted of Cysteine Sulfoxide. Cutting or extracting garlic frees its alliinase enzyme and rapidly turns it into a Sulfonic acid named allicin or de allyl thiosulfinate If another insect or animal reaches garlic, just by cracking its skin, they are forced to go back because of the taste and smell of allicin and its toxic effect. Allicin is a strong insecticid.

Antibacterial effect of garlic because of different materials such as Alliin, Ahoin, allicin and Allistain 1 and 2, and for this reason is used for gram-positive antibacterial and gram-negative antibacterial, fungi, parasites and viruses The best way to extract allicin from garlic is cutting and smashing garlic and putting it in water and alcohol for several times (3). The composition of water and garlic extract can be used in a form of spray to repel insects.

Researchers have found in their researches that the chemical contents of garlic having allicin, de allyl de sulfide and de allyl trisulfide, all have volatile oils and s-allyl Cysteine (SAC) and these compositions include sulfur element.

Sulfur compositions are the factor of creating bad smell in garlic. Allicin is very unstable and after creating harsh smell of garlic is converted to other sulfur compositions including diallyl disulfides, methyl allyl sulfides and dimethyl sulfides and diins and Ajoeins. Garlic has at least 100 types of sulfuric compositions and 70-80\% of them are constituted of allicins (2).

$4 \mathrm{~g}$ of fresh garlic contains approximately $10 \mathrm{mg}$ de alliin and can be converted into at least $4 \mathrm{mg}$ of allicin. Alliin and alliinase are located in separate regions of garlic cloves, and the alliinase reaction is initiated only after the cells have been crushed. Allicin is completely formed in $0.3 \mathrm{~min}$ at $310 \mathrm{~K}$ and, at room temperature, its half-life ranges from 10 days to few hours depending in the solvent in which it is dissolved. Despite allicin being a low-polarity molecule, it is often extracted using polar solvents, such as water and ethanol, at room pressure $(0.1 \mathrm{MPa})$ because it is very unstable in non-polar organic solvents (10). Fujisawa et al.

Fresh Garlic cloves contain about 2-6 mglg of Y-glutamyl-S-allylcysteine $(0.2-0.6 \%$ fresh weight $)$ and 6-14 $\mathrm{mglg}$ of allin ( $0.6-14 \%$ fresh weight). Garlic cloves yield about $2.500-4.500 \mathrm{mg}$ of allicin per gram of fresh weight when crushed. One fresh garlic clove weighs $2-4 \mathrm{~g}$.

Non-fresh no-alliin garlic, $1-7 \mathrm{~g}$ consumption per day is also having the benefits of fresh garlic. The aim of this research is to determine the chemical compositions of garlic plant and investigate the process of producing allicin of garlic. 


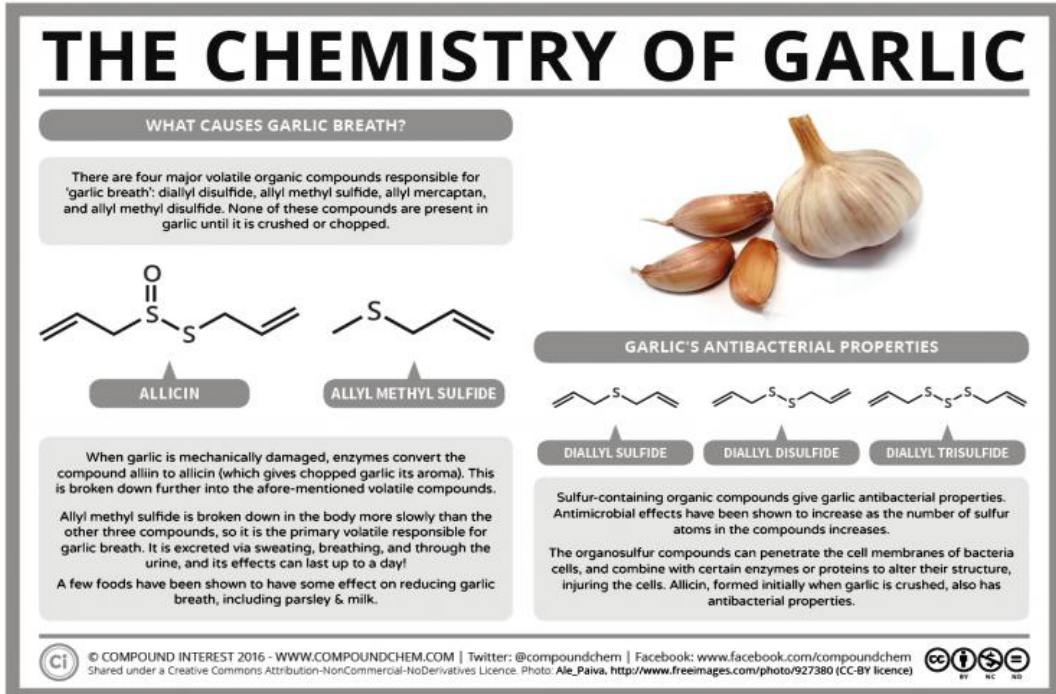

Table 1. Scientific Classification Garlic

\begin{tabular}{|r|r|}
\hline Kingdom: & Planate \\
\hline Clade: & Angiosperms \\
\hline Clade: & Monocots \\
\hline Order: & Asparagales \\
\hline Family: & Amaryllidaceae \\
\hline Subfamily: & Allioideae \\
\hline Tribe: & Allieae \\
\hline Genus: & Allium \\
\hline Species: & A. Sativum \\
\hline Scientific noun: & Allium Sativum L. \\
\hline
\end{tabular}

Smashing garlic grain releases some enzymes called alliinase that converts sulfoxide materials due to sulfonic acid. Then, these acids are converted to aromatic compounds such as allicin and dimmer by losing water .

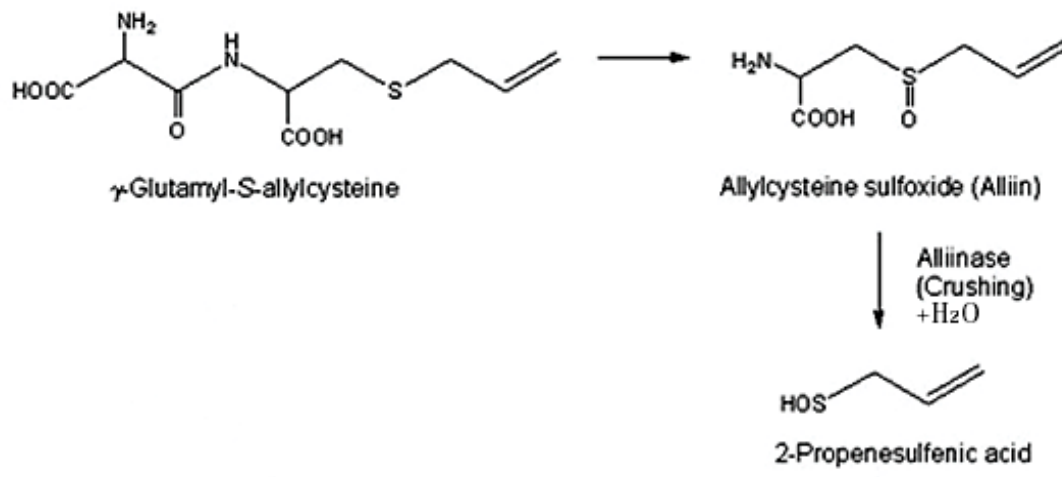

Figure 1: formation of 2-Propenesulfenic acid (Allyl Sulfenic acid)

Allyl Sulfenic acid is unstable and very reactive at room temperature. Whit the elimination of water, two molecules allyl Sulfenic acid condenses spontaneously to allicin.<smiles>C=CC[SH](O)C[SH](O)O</smiles><smiles>C=CCS(=O)CC=CC(C)C</smiles>

Allicin

Figure 2: Biosynthesis of Allicin 


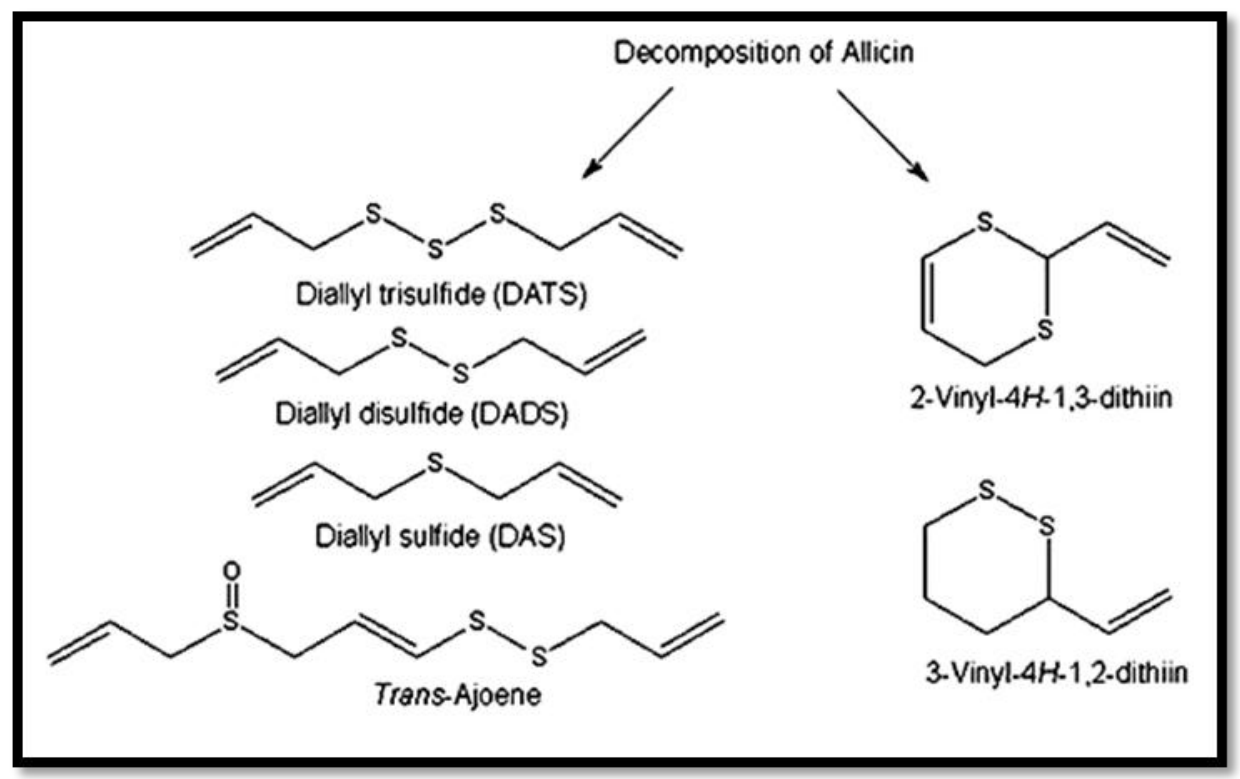

Figure 3: some organosulfur Compounds Derived from Garlic

\section{Components of garlic}

- Amino acids: Glutaminic acid, arginine, aspartic acid, leucine, lysine, valine ... etc

- Minerals: Mainly: manganese, potassium, calcium, phosphorus and in minor quantities: magnesium, selenium. Sodium, iron, zinc and copper.

- Vitamins: Mainly: vitamin B6, also Vitamin C and in minor quantities, folic acid, panthotenic acid and niacin.

- Essential oil with many sulphur-containg components: allyl disulfide, allyl trisulfide, etc

- Alliin, which, by means of enzyme alliinase, is converted into allicin.

- Ajoene, produced by allicin condensation.

- Quercetin.

- Sugars: fructose and glucose.

Table 2. Nutritional composition of Garlic

\begin{tabular}{|c|c|}
\hline \multicolumn{2}{|c|}{ Nutritional composition of garlic $100 \mathrm{gr}$} \\
\hline Water (g) & 59 \\
\hline Calories (kcal) & 149 \\
\hline Lipids (g) & 0,5 \\
\hline Carbohydrates (g) & 33,07 \\
\hline Fiber (g) & 2,1 \\
\hline Manganese (mg) & 1672 \\
\hline Potassium (mg) & 401 \\
\hline Sulphur (mg) & 70 \\
\hline Calcium (mg) & 181 \\
\hline Phosphorus (mg) & 153 \\
\hline Magnesium (mg) & 25 \\
\hline Sodium (mg) & 17 \\
\hline Vitamin B6 (mg) & $1235 \uparrow$ \\
\hline Vitamin C (mg) & 31 \\
\hline Glutamici acid (g) & 0.805 \\
\hline $\operatorname{Arginine}(\mathrm{g})$ & 0,634 \\
\hline Aspartic acid (g) & 0,489 \\
\hline Leucine (g) & 0,308 \\
\hline Lysine (g) & 0,273 \\
\hline
\end{tabular}




\section{Conclusion}

In this research, we investigate the chemical compositions in garlic and also the process of producing allicin inside garlic. With regard to the chemical compositions obtained of garlic, it can be concluded that sulfuric compositions are among active and applicable elements in garlic and allicin is one important sulfuric composition in garlic.

The allicin inside garlic having anti-oxidant feature is useful for human diseases and has antibacterial properties that is used for repelling insects and/or removing insects and is used as one plant agrochemicals as pesticides that is safe for human and environment.

\section{References}

[1]. C. J. Cavallito, J. H. Bailey, Allicin, the antibacterial principle of Allium sativum. Isolation, physical properties and antibacterial action, Journal of the American Chemical Society, vol.66, no.11, pp.1950-1951, 1944.

[2]. M. T. Murray, Ed., J Pizzorno and M Murray, Allium sativum in: Natural Medicine. Kenmore, WA, USA: Churchill Livingstone, 2012.

[3]. Vinay K Singh, Dinesh K Singh. Pharmacological Effects of Garlic (Allium sativum L.). Department of Zoology, DDU Gorakhpur University, Gorakhpur, U.P., INDIA. 2008: 10:6-26. available at http://arbs.biblioteca.unesp.br

[4]. Banerjee Sk., Maulik Sk. Effect of garlic on cardiovascular disorders: a review. Nutj, 2002: (4) 1: 1-14.

[5]. Bergner, Paul. The Healing Power of Garlic. Translator Hasan Rezaaie Rad \& el. (Gom: Mashhor, 2004 ) 270

[6]. Zargari, A. Medicinal Plants. Vol. 4, NO. 6, 620.

[7]. Saberi Najafi, Mohsen. Review Effect of Extract Chloroform Contains Allicin in garlic on Shiglas Entropathogen Toxin Formation, Faculty of medical sciences, Tarbiat Modarres University, MA, 1997.

[8]. Dankert J, Tromp TF, De Vries H, Klasen HJ. Antimicrobial activity of crude juices of Allium ascalonicum,Allium cepa and Allium sativum. Medizinische Microbiologie and parasitologie 1979; 245(1-2):229-39.

[9]. D. R. Eagling, S. J. Sterling, A cholesterol-lowering extract from garlic, Rural Industries Research and Development Corporation, Australia, Tech. Rep. 1-14, 2000

[10]. D. P. Ilić, V. D. Nikolić, L. B. Nikolić, M. Z. Stanković, L. P. Stanojević, M. D. Cakić, Allicin and related compounds: Biosynthesis, synthesis and pharmacological activity, Physics, Chemistry and Technology, vol.9, no.1, pp.9-20, 2011.

[11]. L. Lawson, B. G. Hughes, Characterization of the formation of allicin and other thiosulfinates for garlic, Planta Medica, vol.58, no.4, pp.345-350, 1992

[12]. L. D. Lawson, Ed., AD Kinghorn and MF Balandrin, Bioactive Organosulfur Compounds of Garlic and Garlic Products in: Human Medicinal Agents from Plants. Washington, DC: American Chemical Society, 1993.

[13]. H. Fujisawa, K. Suma, K. Origuchi, H. Kumagai, T. Seki, T. Ariga, Biological and Chemical Stability of Garlic-Derived Allicin, Journal of Agricultural and Food Chemistry, vol.56, no.11, pp.4229-4235, 2008.

[14]. Lawson Ld. Garlic: a review of its medicinal effects and indicated active compounds. Phytomedicines of Europe: chemistry and biological activity. Washington/ D.C.: American chemical society; 1998: 177-209.

[15]. Kannar D., Wattanapen Paaiboon N. \& Savige GS. Hypocholestevolemic effect of an enteric- coated garlic supplement. J. Am. Coll. Nutr. 2001; 20: 225-231.

[16]. Ashraf, R., Aamkhan, R., Ashraf, I., GARLIC (Allium Sativum) Supplementation with standard Antidiabetic Agent Provides Vetter Diabetic control in type 2 diabetes patients. Pak. J. pharm. Sci., Vol. 24. NO. 4, 2011, pp. 565-570.

[17]. Dusica p. Ilie, Vesna D. Nikolic, Ljubisa B. Nikolic, Mihajlo Z. Stankovic, Ljilana p. Stanojevic, Milorad D. Cakic. Allicin and Related compounds: Biosynthesis, Synthesis and Pharmacological Activity. Facta Universitatis: Physics, Chemistry, and Technology. Vol. 9, no. 1, 2011: pp. 9-20. 